\title{
RADIOLOGICAL CHANGES IN THE SACRO-ILIAC JOINTS AND SPINE OF PATIENTS WITH PSORIATIC ARTHRITIS AND PSORIASIS
}

\author{
BY \\ IVO JAJIĆ \\ Splitske Toplice Hospital for Rheumatic Diseases and Rehabilitation, Split, Yugoslavia
}

The radiological changes in the peripheral joints of patients with psoriatic arthritis differ from those in cases of rheumatoid arthritis (Wright, 1961; Lassus, Mustakallio, and Laine, 1964; Sherman, 1952; di Vittorio, Viara, and Chiaudano, 1965; Tesárek, 1966; Sigler, 1966). Changes are also seen in the spine and sacro-iliac joints (Wright, 1961; Lassus and others, 1964; Sherman, 1952; Duthie, 1964; Traut, 1952, Smyth, 1966). In the last few years, many studies have appeared of the radiological changes in the spine in rheumatic diseases (di Vittorio and others, 1965; Traut, 1952; Ortenzi and Tomasini, 1964; Kaplan, Plotz, Nathanson, and Frank, 1964; Lucherini and Porzio, 1965; Robecchi and di Vittorio, 1965; Jajić and Križ, 1966).

In patients with psoriasis, symptoms referable to the spine are unusual without clinical evidence of peripheral arthritis or spinal involvement (Lassus and others, 1964; di Vittorio and others, 1965; Kaplan and others, 1964; Robecchi and di Vittorio, 1965). This paper presents the results of a study of the frequency and nature of involvement of the sacro-iliac joints and spine in patients with psoriatic arthritis (Ps.A) and in patients with psoriasis but without arthritis (Ps.O).

\section{Methods}

$X$ rays were taken of the spine and sacro-iliac joints of 23 patients with Ps.A and 22 patients with Ps.O seen in 1965 and 1966 (Table I). The Ps.A group were 27 to 71 years old (mean 52), and the Ps.O group were 21 to 68 years old (mean 60). $X$ rays were taken of the sacro-iliac joints using the method of Bàrsony, and of the spine using antero-posterior, lateral, and right and left oblique views. Where the interpretation of the sacro-iliac $x$ rays was difficult, tomographs were taken.

The criteria of Hart and Robinson (1959) were used for the radiological diagnosis of sacro-iliitis. Spinal movement was measured by the method of Dürrigl (1961). Sacro-iliac pain on movement and pressure were assessed by the method of Mennell (1945).
TABLE I

DIAGNOSIS, SEX, AND AGE OF SERIES OF 45 PATIENTS

\begin{tabular}{l|c|c|c|c|c}
\hline \multirow{2}{*}{ Diagnosis } & \multicolumn{2}{c|}{ Sex } & \multicolumn{2}{c|}{ Age (yrs) } \\
\cline { 2 - 6 } & Male & Female & Total & Mean & Range \\
\hline Psoriatic Arthritis & 17 & 6 & 23 & 52 & $27-71$ \\
\hline Psoriasis & 18 & 4 & 22 & 60 & $21-68$ \\
\hline Total & 35 & 10 & 45 & & \\
\hline
\end{tabular}

\section{Results}

The average age at the beginning of the skin changes and peripheral arthritis and at the onset of low back pain, and the average duration of these symptoms are listed in Table II.

TABLE II

AGE AT ONSET AND DURATION OF SYMPTOMS

\begin{tabular}{|c|c|c|c|c|c|c|}
\hline Diagnosis & $\cdots$ & $\cdots$ & \multicolumn{2}{|c|}{$\begin{array}{l}\text { Psoriatic } \\
\text { Arthritis }\end{array}$} & \multicolumn{2}{|c|}{ Psoriasis } \\
\hline Sex & . & . & Male & Female & Male & Female \\
\hline \multirow{3}{*}{$\begin{array}{l}\text { Average } \\
\text { Age } \\
\text { (yrs) }\end{array}$} & \multicolumn{2}{|c|}{$\begin{array}{l}\text { At onset of skin } \\
\text { lesions }\end{array}$} & 35 & 23 & 32 & 25 \\
\hline & \multicolumn{2}{|c|}{ At onset of arthritis } & 43 & 40 & & \\
\hline & \multicolumn{2}{|c|}{$\begin{array}{l}\text { At onset of low } \\
\text { back pain }\end{array}$} & 43 & 32 & & \\
\hline \multirow{3}{*}{$\begin{array}{l}\text { Average } \\
\text { Duration } \\
\text { (yrs) }\end{array}$} & \multicolumn{2}{|c|}{ Of skin lesions } & 16 & 23 & 13 & 9 \\
\hline & \multicolumn{2}{|c|}{ Of arthritis } & 11 & 9 & & \\
\hline & \multicolumn{2}{|c|}{ Of low back pain } & 10 & 10 & & \\
\hline
\end{tabular}

Of the patients with Ps.A, skin lesions appeared first in nineteen ( 82 per cent.). In one patient, arthritis, low back pain, and skin lesions appeared simultaneously. In fourteen (60 per cent.), low back pain preceded the appearance of arthritis. In three (13 per cent.) arthritis preceded the onset of skin lesions.

Detailed analysis of the $x$ rays of the sacro-iliac joints revealed inflammatory changes similar to ankylosing spondylitis, and the changes of osteoarthritis. Inflammatory changes were more commonly seen in Ps.A and in cases with psoriasis and 
low back pain than in the Ps.O group, and the lesions commonly seen were extensive erosions with usurae* and sclerosis of joint margins, in contrast to idiopathic ankylosing spondylitis in which the joint margins are jagged like the perforated edges of a postage stamp.

Sclerosis was more common than osteoporosis in both groups (Table III).

TABLE III

CLASSIFICATION OF RADIOLOGICAL CHANGES OF SACRO-ILIAC JOINTS

\begin{tabular}{|c|c|c|c|c|}
\hline \multirow{3}{*}{$\begin{array}{c}\text { Radiological } \\
\text { Changes }\end{array}$} & \multicolumn{4}{|c|}{ Diagnosis } \\
\hline & \multicolumn{2}{|c|}{ Psoriatic Arthritis } & \multicolumn{2}{|c|}{ Psoriasis } \\
\hline & Unilateral & Bilateral & Unilateral & Bilateral \\
\hline Erosions & 1 & 13 & 1 & 5 \\
\hline *Usurae & 3 & 9 & 1 & 5 \\
\hline Osteoporosis & & 8 & & 1 \\
\hline Sclerosis & & 17 & 1 & 5 \\
\hline Joint space changes & 4 & 9 & 1 & 4 \\
\hline Ankylosis & 3 & 6 & & \\
\hline Osteophytes & & 4 & 1 & 4 \\
\hline
\end{tabular}

While the osteoporosis was diffuse, sclerosis was more marked at the joint margins and around erosions (Fig. 1).

*The term "usurae" describes large erosions involving the joint surface.
Sclerosis was more commonly seen in the ilium $\frac{\text { गु }}{2}$ than in the sacrum (Fig. 2, opposite) and appeared similar to osteitis condensans ilii.

The incidence and stage of sacro-iliitis is given in $\frac{\square}{\omega}$. Table IV. Where bilateral changes were present, they were usually asymmetrical. Changes of osteoarthritis were seen in four male and one female 0 with Ps.A.

TABLE IV

STAGE OF SACRO-ILIITIS

\begin{tabular}{|c|c|c|c|c|c|}
\hline \multirow[b]{2}{*}{ Diagnosis } & \multirow[b]{2}{*}{. } & \multicolumn{2}{|c|}{ Psoriatic Arthritis } & \multicolumn{2}{|c|}{ Psoriasis } \\
\hline & & $\begin{array}{c}\text { Number } \\
\text { of } \\
\text { Patients }\end{array}$ & $\begin{array}{l}\text { Number } \\
\text { of Joints } \\
\text { Involved }\end{array}$ & $\begin{array}{c}\text { Number } \\
\text { of } \\
\text { Patients }\end{array}$ & $\begin{array}{l}\text { Number } \\
\text { of Joints } \\
\text { Involved }\end{array}$ \\
\hline \multirow{4}{*}{$\begin{array}{l}\text { Stage } \\
\text { of } \\
\text { Sacro- } \\
\text { iliitis }\end{array}$} & I & 7 & 10 & 1 & 1 \\
\hline & II & 10 & 12 & 5 & 10 \\
\hline & III & 5 & 6 & & \\
\hline & IV & 4 & 8 & & \\
\hline
\end{tabular}

The spinal abnormalities are listed in Table $\mathrm{V}-$ (opposite).

Erosive changes in the small intervertebral joints were common, and in two patients erosions were seen on the vertebral bodies adjacent to the inter- vertebral disk (Fig. 3, overleaf). Narrowing of the apophyseal joint spaces and intervertebral disks wese. seen most commonly in the lower lumbar spine both Ps.A and Ps.O, and was considered to be a sign

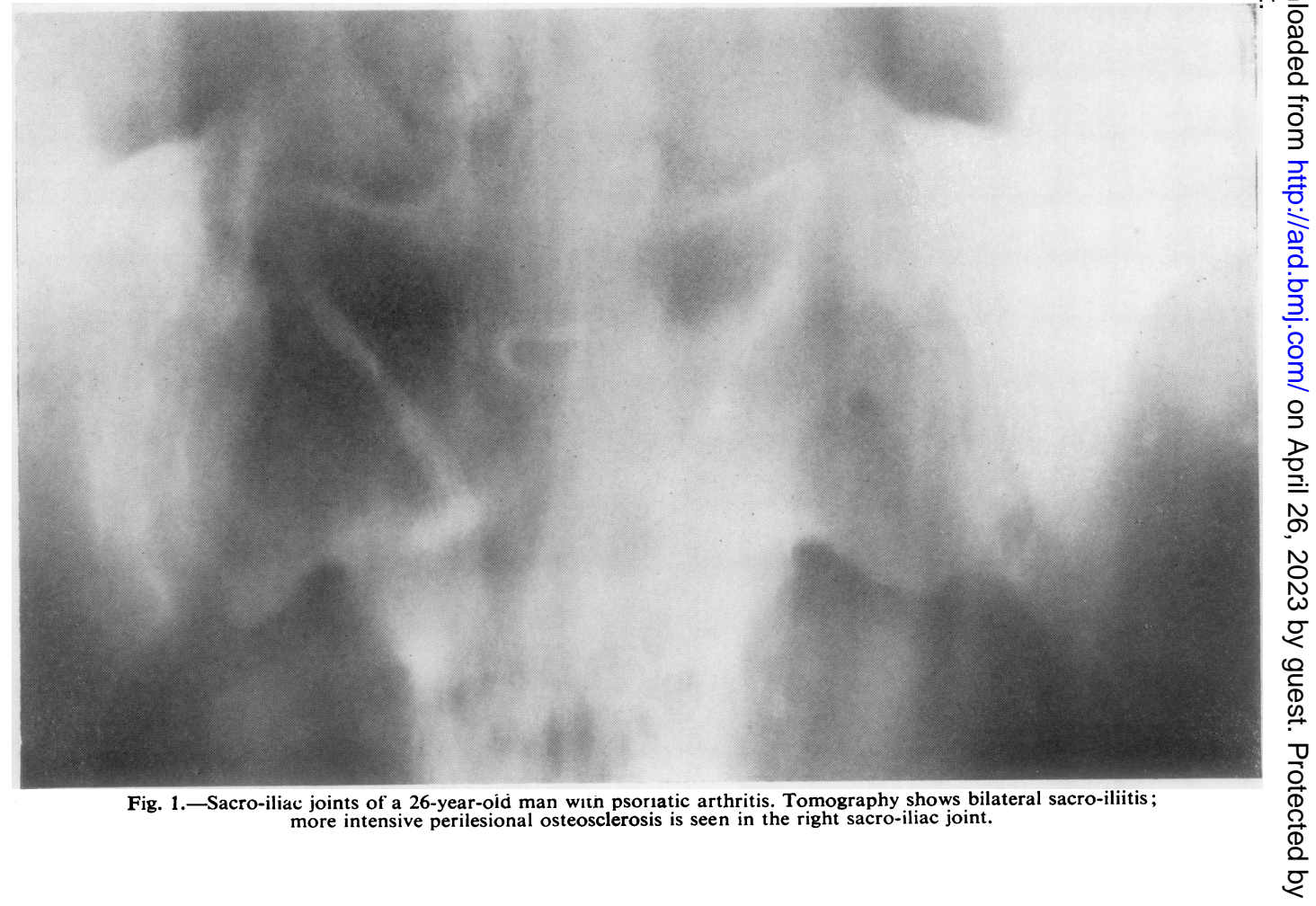




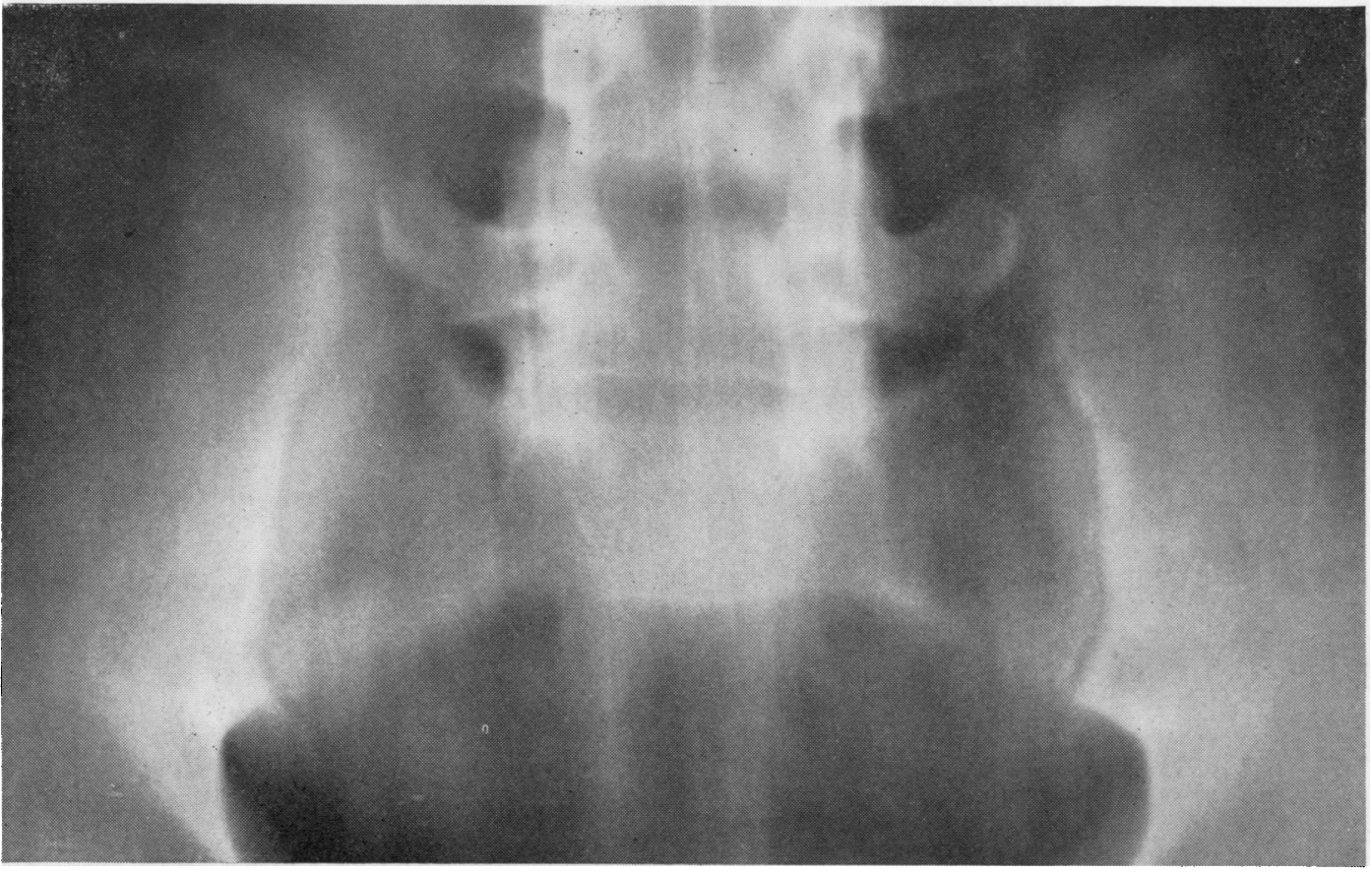

Fig. 2.-Sacro-iliac joints of a 39-year-old man with psoriasis, showing para-articular osseous condensation which is more marked on the ilium than the sacrum.

TABLE V

CLASSIFICATION OF THE RADIOLOGICAL CHANGES IN THE SPINE

\begin{tabular}{l|c|c}
\hline \multirow{2}{*}{ Radiological Changes } & \multicolumn{2}{|c}{ Diagnosis } \\
\cline { 2 - 3 } & $\begin{array}{c}\text { Psoriatic } \\
\text { Arthritis }\end{array}$ & Psoriasis \\
\hline Erosion & 14 & 2 \\
\hline Usurae & 12 & - \\
\hline Osteoporosis & 10 & 2 \\
\hline Sclerosis & 13 & 4 \\
\hline Joint space changes & 14 & 9 \\
\hline Syndesmophytes & 12 & 5 \\
\hline Squaring & 3 & - \\
\hline Ankylosis & 1 & - \\
\hline Osteophytes & 15 & 10 \\
\hline Ossification of interspinous ligaments & 3 & - \\
\hline Changes in costo-vertebral joints & 3 & 2 \\
\hline Ossification of ilio-lumbar ligaments & 3 & 2 \\
\hline
\end{tabular}

of degenerative joint disease. Syndesmophytes were most common in the thoraco-lumbar spine and were more common with Ps.A than Ps.O (Figs 4 and 5, overleaf); they were usually single, and when bilateral, were not symmetrical. The type of ossification which produces the bamboo spine appearance, which is common in ankylosing spondylitis, was not seen in these patients. All patients who had syndesmophytes showed changes in the sacro-iliac joints. Ossification of the interspinous ligaments was seen in two patients (Fig. 6) and of the ilio-lumbar ligament in four. Vertebral squaring was present in three (Fig. 7). Intervertebral disk calcification was seen in one.

Only five patients complained of low back pain or morning stiffness of sufficient severity to interfere with their ability to work. There was no correlation between radiological abnormalities of the sacroiliac joints and spine and impairment of spinal movement. Mennell's sign was positive most frequently in patients with Stage 1 and 2 sacro-iliitis, less so in Stage 3, and never in Stage 4.

\section{Discussion}

Sterne and Schneider (1953) found changes in the sacro-iliac joints in two out of six cases with Ps.A. Graber-Duvernay (1957) found changes in 23 patients with psoriasis, which were similar to those of ankylosing spondylitis. Wright (1961) found that sacro-iliitis was more common in psoriasis than in rheumatoid arthritis. Robecchi, di Vittorio, and Masrazzi (1961) described changes which were more like osteitis condensans ilii. In five out of sixty cases of Ps.A, Baker, Golding, and Thompson (1963) found spinal or sacro-iliac changes. Lassus and others (1964), in 169 cases of Ps.A, found spinal involvement in 3.6 per cent. and sacro-iliac involve- 


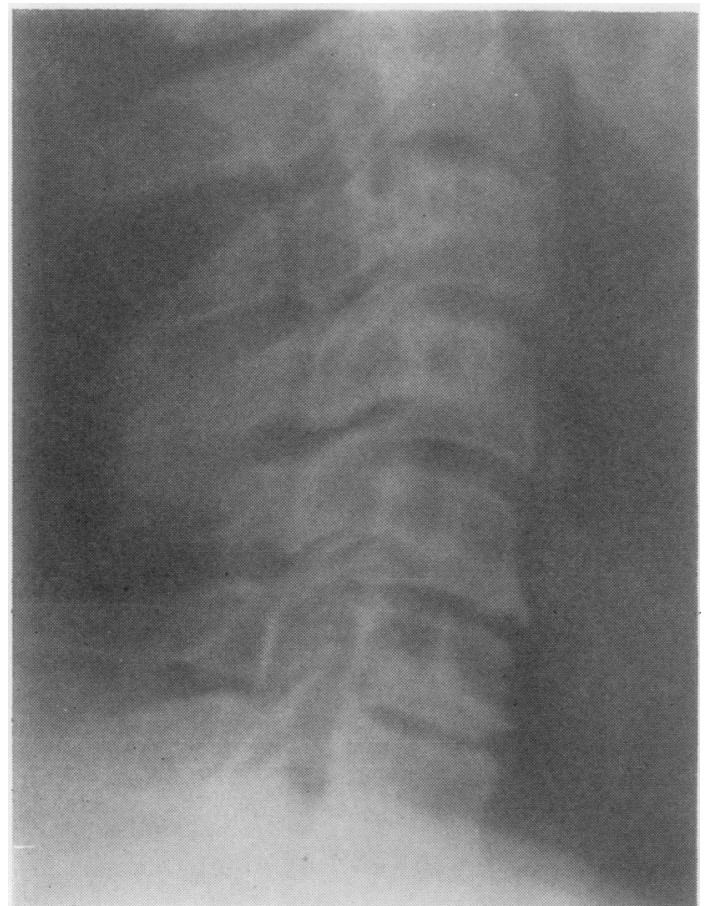

Fig. 3.-Cervical spine of a 64-year-old man with psoriatic arthritis, showing extensive destructive changes of the lower surface of $\mathrm{C} 6$ and the upper surface of $\mathrm{C7}$.

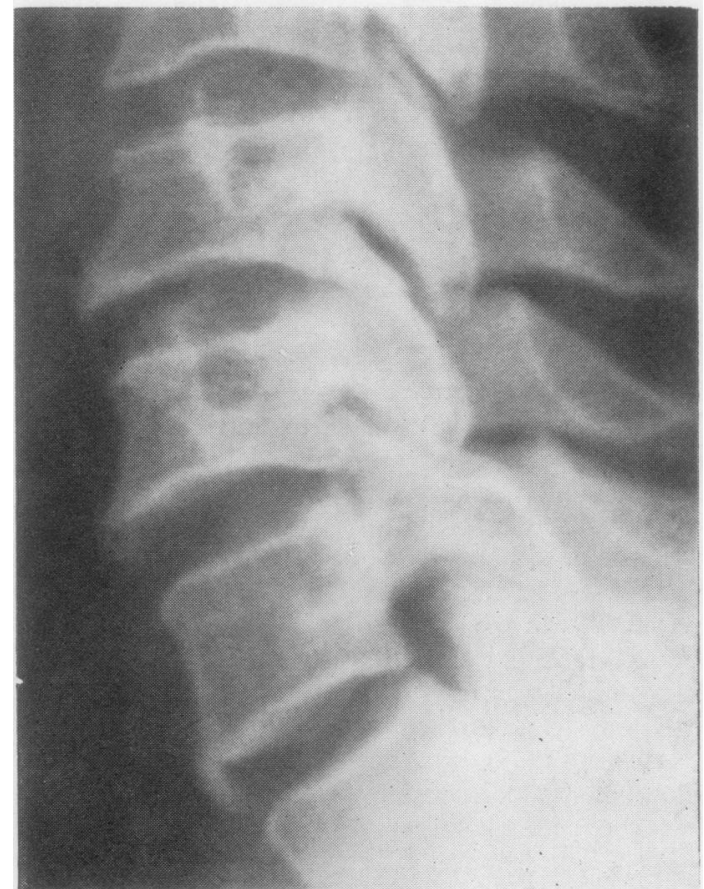

Fig. 5.-Cervical spine of a 55-year-old man with psoriatic arthritis showing ossification of the anterior longitudinal ligament between C6-7 and C7-T1.

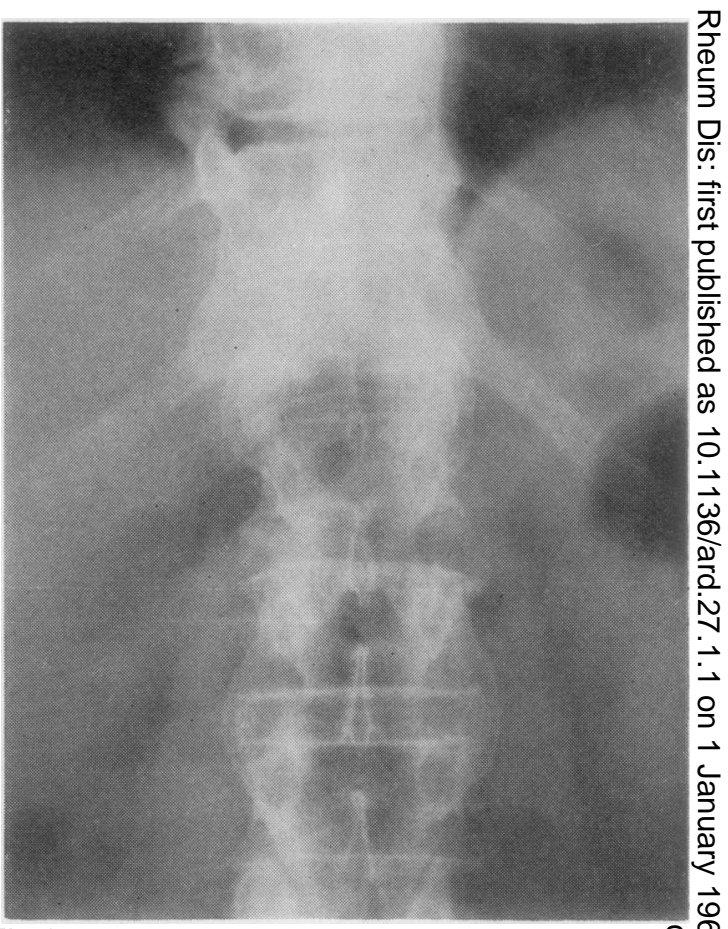

Fig. 4.-Thoraco-lumbar spine of a 58-year-old man with psoriatco arthritis. These are syndesmophytes especially between T12 and 1 and L2-3.

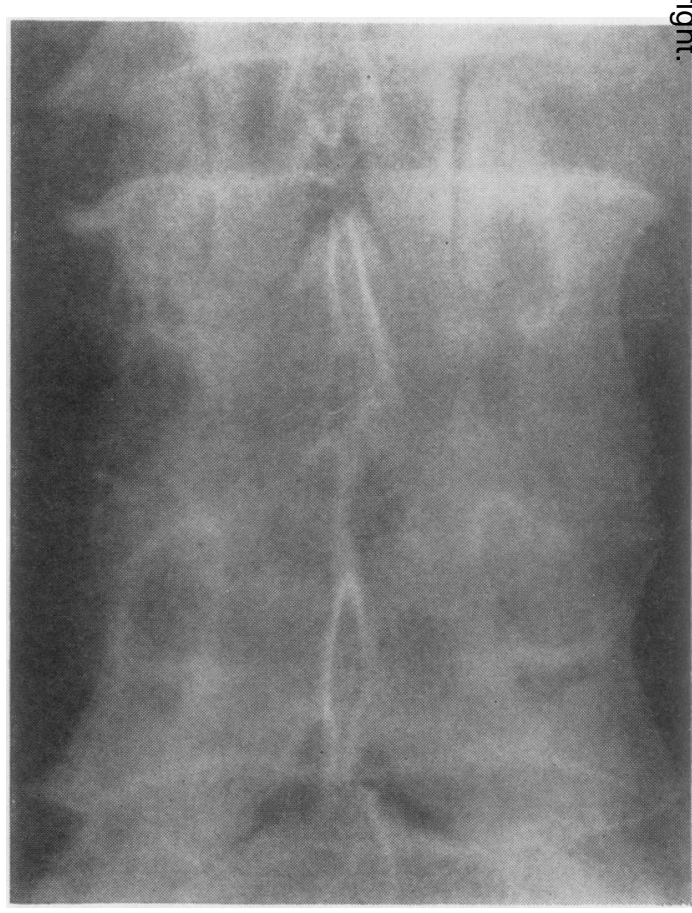

옹

Fig. 6.-Lumbar spine of a 61-year-old man with psoriatic arthritis, showing ossification of the inter- and supraspinous ligaments between L3-4.

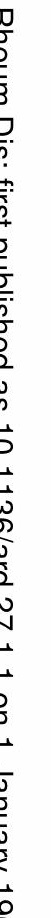




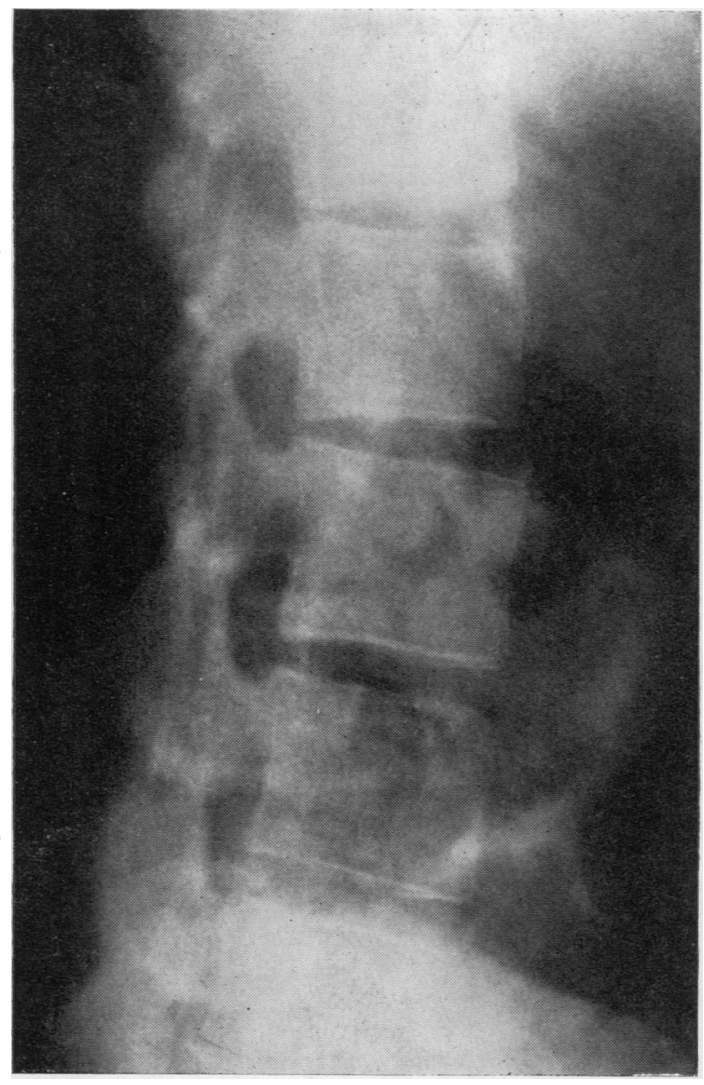

Fig. 7.-Lumbar spine of a 26-year-old man with psoriatic arthritis. Vertebrae L1-2 shows typical squaring; vertebrae L3-4 shows early squaring.

ment in $14 \cdot 2$ per cent., spinal osteoporosis being more common in rheumatoid arthritis than in Ps.A. Kaplan and others (1964) found changes in the cervical spine in Ps.A which were different from those of rheumatoid arthritis and ankylosing spondylitis. di Vittorio and others (1965) and Bywaters and Dixon (1965), examining cases of Ps.A and Ps.O, found sacro-iliac and spinal changes which differed from those of ankylosing spondylitis.

Extensivesubchondral ossification, especially on the ilium, which was seen in our patients, has been previously reported (di Vittorio and others, 1965; Robecchi and others, 1961 ; Robecchi and di Vittorio, 1965).

Radiological analysis has shown that sacro-iliac changes were more common than spinal changes and that both were more common in Ps.A than Ps.O. Spinal changes included osteophytes, syndesmophytes, and disk space narrowing. In those patients who maintained a good range of movement, there was a tendency to develop osteophytes, whereas syndesmophytes were associated with limitation of movement. In three patients in whom syndesmo-

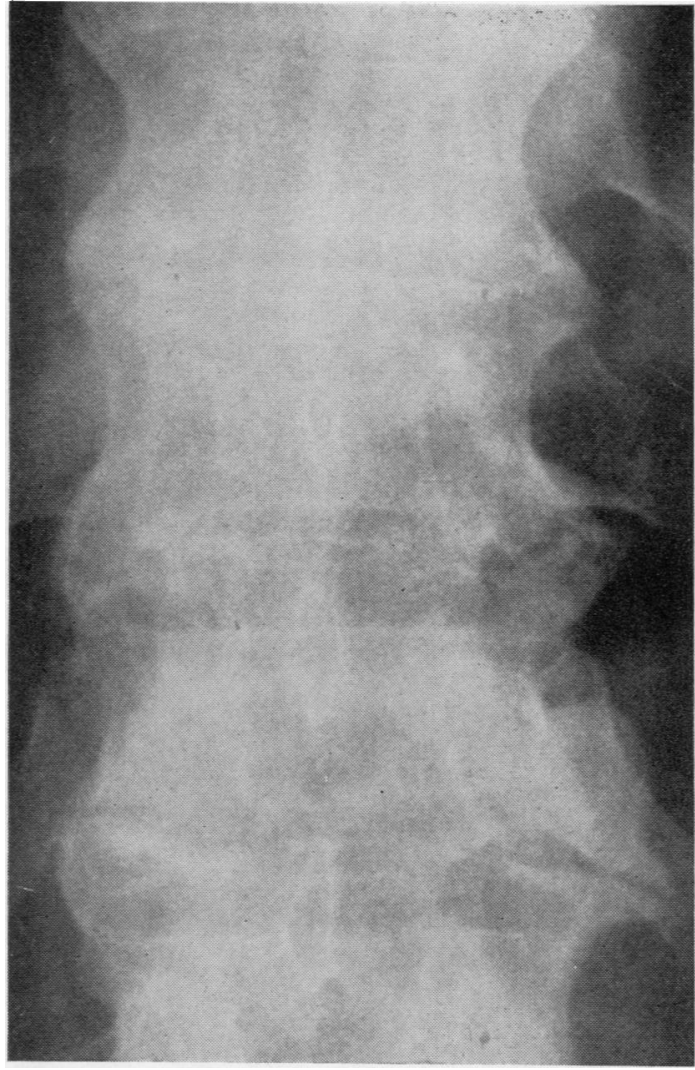

Fig. 8.-Thoraco-lumbar spine of a 61-year-old man with psoriatic arthritis.

phytes developed slowly over 2 years, increasing limitation of movement was found. In this series, syndesmophytes were seen most frequently in the thoraco-lumbar region as found by Bywaters and Dixon (1965), although some authors have reported that they occur more often in the cervical spine (Kaplan and others, 1964; Lucherini and Porzio, 1965; Graber-Duvernay, 1957).

The changes seen in the sacro-iliac joints, the syndesmophytes, the ossification of the joint capsule and interspinous ligaments, and squaring of the intervertebral bodies are characteristic of ankylosing spondylitis (Bywaters and Dixon, 1965; Lucherini and Porzio, 1965; Robecchi and di Vittorio, 1965; Jajić and Križ, 1966). In view of the frequency of sacro-iliac and spinal changes in our cases, we think that a chance association between psoriasis and ankylosing spondylitis can be excluded, and we suggest that they represent a separate entity for which the title spondylitis psoriatica is proposed. The nature of the relationship between psoriasis and arthritis remains obscure. 


\section{Summary and Conclusions}

Radiological examination of the sacro-iliac joints and spine was performed on 23 patients with psoriatic arthritis (Ps.A) and 22 with psoriasis without arthritis (Ps.O). In the majority of cases of Ps.A, syndesmophytes and sacro-iliac changes were present. Calcification of the interspinous ligaments were seen in three and of the ilio-lumbar ligamen in two. Vertebral squaring was present in three.

Osteophytes and disk narrowing were seen less often and were thought to represent degenerative disease. Mobility of the spine was usually main tained. It is suggested that these changes are characes teristic of a disease entity which may be describedo as "psoriatic spondylitis".

\section{REFERENCES}

Baker, H., Golding, D. N., and Thompson, M. (1963). Ann. intern. Med., 58, 909 (Psoriasis and arthritis).

Bywaters, E. G. L., and Dixon, A. St.J. (1965). Ann. rheum. Dis., 24, 313 (Paravertebral ossification in psoriatic arthritis).

di Vittorio, S., Viara, M., and Chiaudano, M. (1965). Reumatismo, 17, 336 (Il quadro radiologico dell'artrite psoriasica).

Dürrigl, T. (1961). Liječn. Vjesn.. 83, 883 (Sagittal flexibility of the spinal column).

Duthie, J. J. R. (1964). In "Textbook of the Rheumatic Diseases", ed. W. S. C. Copeman, 3rd ed. Livingstone, Edinburgh and London.

Graber-Duvernay, J. (1957). Rev. Rhum., 24, 288 (À propos de la spondylarthrite psoriasique).

Hart, F. Dudley and Robinson, K. C. (1959). Ann. rheum. Dis., 18, 15 (Ankylosing spondylitis in women).

Jajić, I., and Križ, L. (1966). Liječn. Vjesn., 88, 395 (Spondylitis psoriatica).

Kaplan, D., Plotz, C. M., Nathanson, L., and Lawrence, F. (1964). Ann. rheum. Dis., 23, 50 (Cervical spine in psoriasis and in psoriatic arthritis).

Lassus, A., Mustakallio, K. K., and Laine, V. (1964). Acta rheum. scand., 10, 62 (Psoriasis arthropathy and rheumatoid arthritis. A roentgenological comparison).

Lucherini, T., and Porzio, F. (1965). Reumatismo, 17, 49 (Spondilite anchilosante psoriasica).

Mennell, J. B. (1945). "Physical treatment by movement, manipulation and massage"; 5th ed., Churchill, London.

Ortenzi, E., and Tomasini, C. (1964). Reumatismo, 16, 364 (A proposito dell'osteoartropatia psoriasica. Presentazione di un caso con spondilo-sacro-iliite di tipo anchilosante).

Robecchi, A., and di Vittorio, S. (1965). Minerva derm., 40, 129 (La spondilartrite psoriasica).

,-- , and Marrazzi, G. (1961). Reumatismo, 13, 49 (Psoriasie artropatie).

Sherman, M. S. (1952). J. Bone Jt Surg., 34A, 831 (Psoriatic arthritis).

Sigler, J. W. (1966). In “Arthritis and Allied Conditions", ed. J. L. Hollander, 7th ed., p. 656. Lea and Febiger, Philadelphia.

Smyth, C. J. (1966). Idem.

Sterne, E. H., and Schneider, B. (1953). Ann. intern. Med., 38, 512 (Psoriatic arthritis).

Tesárek, B. (1966). Vnitřni Lék., 12, 486

Traut, E. F. (1952). "Rheumatic Diseases: Diagnosis and Treatment", Mosby, St. Louis.

Wright, V. (1961). Ann. rheum. Dis., 20, 123 (Psoriatic arthritis: a comparative radiographic study of rheumatoid arthritis and arthritis associated with psoriasis).

Les altérations radiologiques des articulations sacroiliaques et de la colonne vertébrale chez les malades atteints d'arthrite psoriasique et de psoriasis.

On procéda à l'examen radiologique des articulations sacro-iliaques et de la colonne vertébrale chez 23 malades ayant une arthrite psoriasique et chez 22 malades ayant un psoriasis sans atteinte articulaire. Dans la plupart des cas d'arthrite psoriasique on trouva des syndesmophytes et une atteinte des sacro-iliaques. On a observé dans trois cas la calcification des ligaments interépineux et dans deux cas du ligament iliolombaire. Un aspect anguleux des vertèbres fut observé dans trois cas.

Des ostéophytes et un pincement discal furent trouvés moins souvent et furent considérés comme atteinte dégénérative. Généralement la mobilité de la colonne vertébrale était préservée. On suggère que ces altérations caractérisent une entité morbide à laquelle on peut donner le nom de "spondylite psoriasique".
Las alteraciones radiológicas de las articulaciones sacro ilíacas y de la columna vertebral en enfermos con artriti오 psoriásica y con psoríasis

Se examinaron radiológicamente las articulacione오. sacroilíacas y vertebrales de 23 enfermos con artritis. psoriásica y de 22 enfermos con psoríasis sin afecciórf articular. En la mayoría de los casos de artritis psoriásica se encontraron sindesmofitos y alteraciones sacro ilíacas. En tres casos hubo calcificación de los ligamentos్ interespinosos y en dos casos del ligamento ilíolumbar La cuadratura (squaring) vertebral fué vista en tres casos.

Osteofitos y estrechamiento discal se encontraron cop

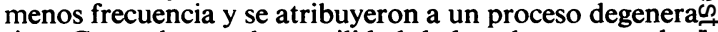
tivo. Generalmente la movilidad de la columna vertebral se mantuvo. Se sugiere que estas alteraciones cracterizant una entidad morbosa que se puede nombrar "espondiliti蔗 psoriásica". 